\title{
A Shear Reynolds Number-Based Classification Method of the Nonuniform Bed Load Transport
}

\author{
Gergely T. Török ${ }^{1,2, * \mathbb{D}}$, János Józsa ${ }^{1,2}$ and Sándor Baranya ${ }^{2}$ \\ 1 MTA-BME Water Management Research Group, Hungarian Academy of Science-Budapest University of \\ Technology and Economics, Múegyetem rakpart 3, H-1111 Budapest, Hungary; jozsa.janos@epito.bme.hu \\ 2 Department of Hydraulic and Water Resources Engineering, Faculty of Civil Engineering, Budapest \\ University of Technology and Economics, Múegyetem rakpart 3, H-1111 Budapest, Hungary; \\ baranya.sandor@epito.bme.hu \\ * Correspondence: torok.gergely@epito.bme.hu; Tel.: +36-1-463-2248
}

Received: 30 November 2018; Accepted: 24 December 2018; Published: 3 January 2019

check for updates

\begin{abstract}
The aim of this study is to introduce a novel method which can separate sand- or gravel-dominated bed load transport in rivers with mixed-size bed material. When dealing with large rivers with complex hydrodynamics and morphodynamics, the bed load transport modes can indicate strong variation even locally, which requires a suitable approach to estimate the locally unique behavior of the sediment transport. However, the literature offers only few studies regarding this issue, and they are concerned with uniform bed load. In order to partly fill this gap, we suggest here a decision criteria which utilizes the shear Reynolds number. The method was verified with data from field and laboratory measurements, both performed at nonuniform bed material compositions. The comparative assessment of the results show that the shear Reynolds number-based method operates more reliably than the Shields-Parker diagram and it is expected to predict the sand or gravel transport domination with a $<5 \%$ uncertainty. The results contribute to the improvement of numerical sediment transport modeling as well as to the field implementation of bed load transport measurements.
\end{abstract}

Keywords: bed load transport; shear Reynolds number; mixed-size bed material; complex morphodynamics

\section{Introduction}

In terms of typical geomorphological features, rivers can be divided into three main section types: upper, middle and lower course [1]. One of the decisive differences among these river features is the erosion capacity of the flow, which constantly decreases along the river. In fact, it can be stated that the erosion prevails along the upper course rivers, yielding coarser gravel bed material and significant bed load transport. As to the middle course, all the three characteristic sediment transport processes, such as the local erosion of the bed, the transport of coarse and fine particles together with river bed aggradation take place. Finally, the lower course type rivers can be generally characterized with the deposition of fine sediments transported from upstream. Due to the spatially and temporally varying bed load transport capacity of the flow and the changing river planforms (straight, meandering, or braided river channel patterns [2]), the morphological features can also show significant variability.

Many classification methods can be found in the literature to describe the morphological properties of river sections (e.g., [3-7]). The main goal of these tools is to typify and predict the dominant morphological properties and processes, such as defining the predominant sediment transport mode (bed load, or suspended load) [8], the channel pattern type [1,9], the specific bed material grain size [7], the erosion capacity [10], or the bed armor measure [6]. According to these methods, the morphological 
properties and processes can be estimated as the function of a few hydro-morphological variables, e.g., the water depth, the channel width, the mean flow velocity, the mean grain size of the bed material, or the longitudinal bed slope.

For instance, there are classification methods, suggesting that the dominant grain size of the bed load (sand or gravel) can be obtained based on the $d_{50}$ grain size of the bed material [8]. In most cases, such a classification is straightforward due to the fact that a dominant bed material fraction can be chosen, considering, e.g., sand-bed $\left(d_{50}<2 \mathrm{~mm}\right)$ or gravel-bed $\left(d_{50}>2 \mathrm{~mm}\right)$ streams [8]. However, there are several situations, when such a clear distinction cannot be made as both sand- and gravel-dominated zones appear even in shorter river reaches. Moreover, the locally dominant bed load fraction can alter according to the current flow conditions. So, only the motion of finer particles of a nonuniform bed material can occur during low-water regime. In turn, the higher flood waves increase the sediment transport capacity of the flow, resulting in probably gravel-dominated bed load. That is, because the bed load is mainly fed by the bed itself [11], very different grain sizes can characterize the bed load transport within river sections with mixed-size bed material. These sections are typical to middle-course rivers, at the transition sections in terms of bed material.

\section{Case Study}

Such a river reach is the upper Hungarian Danube reach between rkm 1798 and rkm 1795 (Figure 1). At this section, the middle course resulted in a meandering pattern type, with nonuniform bed material ( $d_{50}$ ranges between 0.32 and $\left.70.5 \mathrm{~mm}\right)$ [9,12]. Furthermore, conventional river regulation measures (e.g., groin fields) were installed, which further enhanced the diversity of the morphological properties and processes [13-17]. The following parameters characterize the river: the main channel width at mean water regime ranges between $150 \mathrm{~m}$ and $350 \mathrm{~m}$; the average water surface gradient is around 0.0002-0.00025 [17], whereas the characteristic flow discharges are $Q_{m}=2000 \mathrm{~m}^{3} / \mathrm{s}$ (mean flow), $Q_{b f}=4300-4500 \mathrm{~m}^{3} / \mathrm{s}$ (range of bankfull discharge), $Q_{100}=10,400 \mathrm{~m}^{3} / \mathrm{s}$ (100 year flood event) [18] and $Q_{200}=\sim 10,800 \mathrm{~m}^{3} / \mathrm{s}$ (200 year flood event) [19]. Here, the dominant fraction in the bed material, and hence in the bed load, shows a strongly varying spatial distribution. That is, bed armoring and gravel bed load takes place in the main channel, while clear sand transport can be observed in the near-bank zones and in the groin fields. Finally, the accumulation and erosion of the gravel-sand mixture is detectable at some places, resulting in the formation of side bars (Figure 1).

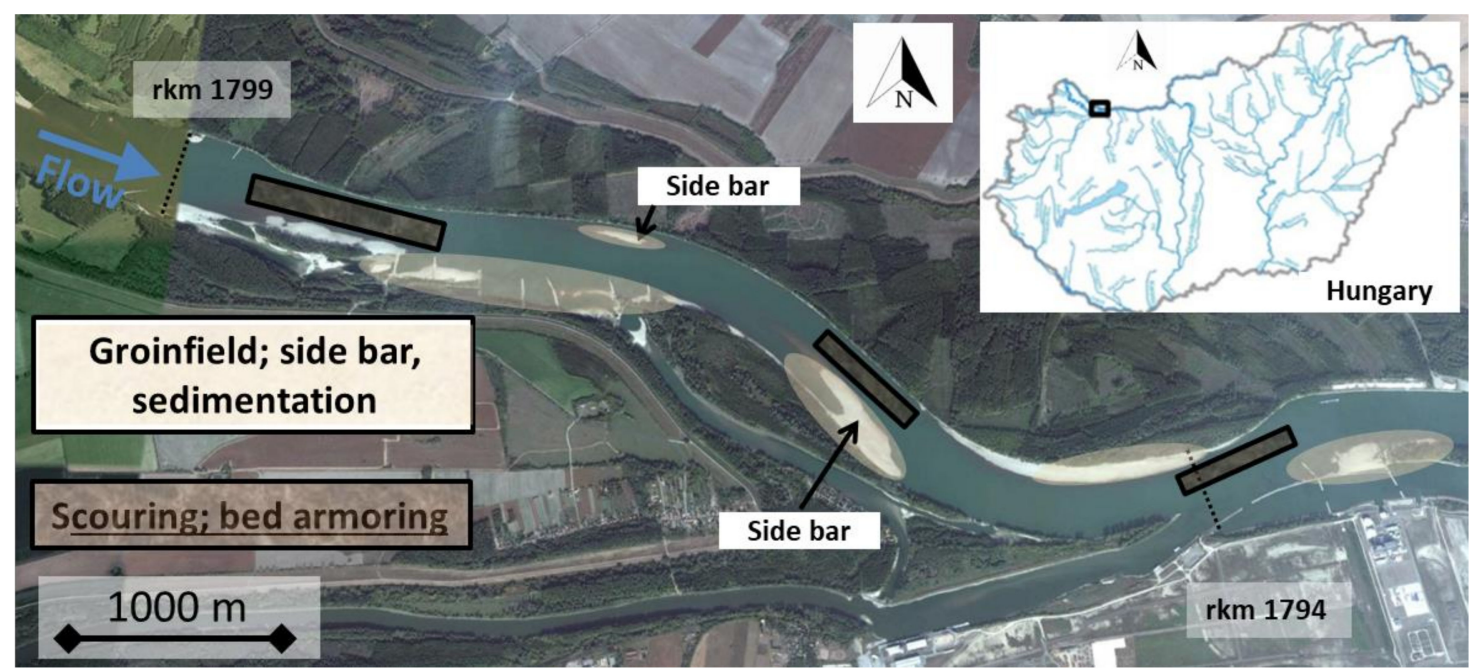

Figure 1. The sketch of the investigated section of the Danube River.

The herein-presented study focuses on this issue: how the dominant fraction of the bed load transport can be determined, when both the river hydrodynamics and the morphological features show strong heterogeneity within the studied reach. When local or reach-scale morphodynamic analysis is 
carried out, it is far from evident what sort of empirical sediment transport formula to use. There can be found formulas for finer fractions (e.g., [20]), as well as for coarser fractions (e.g., [21]), both having limitations when considering mixed-size bed material. However, no such straightforward method can be found in the literature, which suggests the locally dominant bed load transport mode and thus the more suitable formula for nonuniform bed material. An attempt is made in this study to fill this gap, providing a methodology that works more accurately compared to earlier published methods.

\section{Materials and Methods}

\subsection{Problem Statement}

Significant variability of the dominant grain size in the bed load can take place in nonuniform bed material, e.g., in the case of the investigated Danube reach. Figure 2 shows the density function of a bimodal bed material sample, collected from the lower side bar (see Figure 1, green columns, left vertical axis). The black line (and the right vertical axis) represents the critical dimensionless bed shear stress values (or critical Shields number, Equation (1)), as the function of the grain size, calculated by the Shields curve [22]. If the dimensionless bed shear stress exceeds the critical value, the given particle is in motion, otherwise it stays calm.

$$
\tau^{*}=\frac{\tau}{g\left(\rho_{s}-\rho_{w}\right) d^{\prime}}
$$

where $\tau^{*}$ is the Shields number, $\tau$ is the bed shear stress, $g$ is the acceleration due to gravity, $\rho_{S}$ is the sediment density, $\rho_{w}$ is the water density and $d$ is the grain diameter.

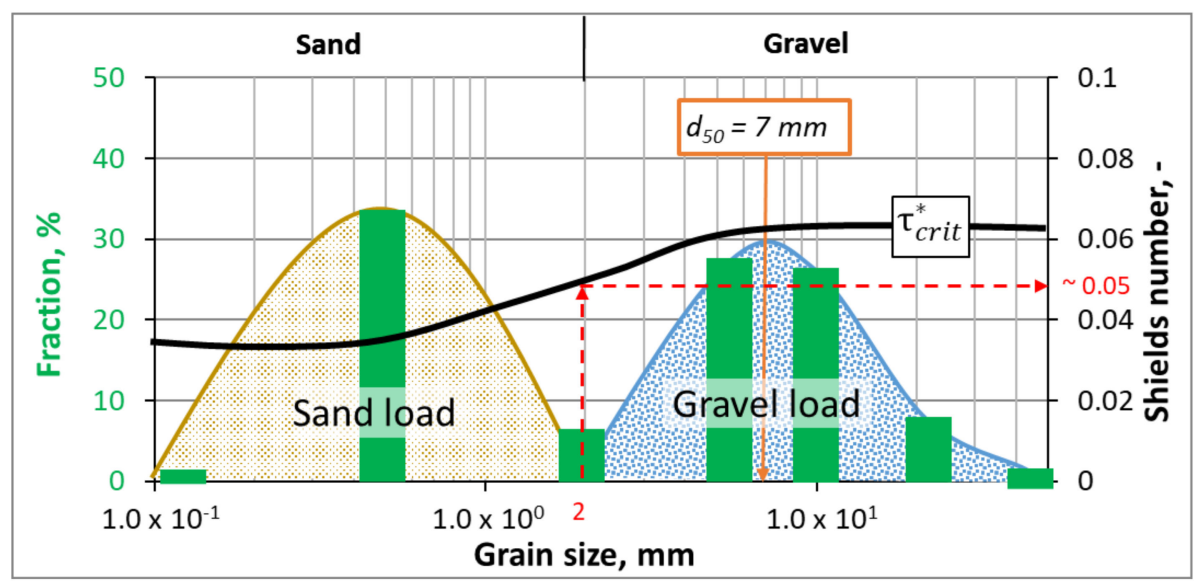

Figure 2. The density function of a bed material sample collected from a side bar (green curve).

The Shields curve-related critical bed shear stress values are depicted by the black line.

As the fraction rates indicate, sand and gravel also appear well separately, both with significant amount $(>30 \%)$. The grain size distribution indicates a $d_{50}$ of $7 \mathrm{~mm}$, which would refer to gravel transport. However, examining the critical Shields numbers, it turns out that the dominant bed load grain size seems to be inconstant, varying depending on the flow conditions. If the dimensionless bed shear stress is in a lower range $\left(\tau^{*}<\sim 0.05\right.$, or equivalently $\left.\tau<\sim 2 \mathrm{~N} / \mathrm{m}^{2}\right)$, only sand $(<2 \mathrm{~mm})$ movement can be expected. In turn, increasing dimensionless bed shear stress $\left(\tau^{*}>0.05\right.$, or equivalently $\tau>\sim 2 \mathrm{~N} / \mathrm{m}^{2}$ ) results in the motion of even the coarser gravels ( $>2 \mathrm{~mm}$ ), while the motion of the finer sand fraction tends to be rather suspended, like rolling [8], resulting in even coarser bed load. Concluding the above, the $d_{50}$ grain size of the bed material itself is not able to indicate the current dominant grain size in the bed load, especially not in the case of nonuniform bed material under varying flow conditions (for further similar study cases see, e.g., [23,24]). 
When implementing computational morphodynamic models in cases like the above-presented mixed-size bed material, the variable dominant fraction in the bed load can lead to inappropriate application of sediment transport models. Nevertheless, the numerical simulation of morphodynamic processes can contribute to the better performance of river engineering activities, e.g., when planning restoration measures, and it is considered a widely applied investigation tool with many benefits. However, the reliable numerical description of the interaction between river hydrodynamics and the morphological features is a challenging task in rivers with uniform bed material composition, but shows even higher difficulties in the case of mixed-size bed material conditions (e.g., [25-29]). When the grain sizes cover a smaller range in the bed material, the potential erosion results also in a quite uniform grain size range of the bed load transport. For such conditions, many bed load sediment transport models have already been developed and successfully validated [22,30-33]. On the other hand, the choice of the bed load sediment transport formula is still a challenge when the characteristic grain sizes can significantly change both in time and space [23,25,34-36]. Accordingly, the most suitable numerical formula can change in time and space. For instance, as many studies present [34,37-44], the van Rijn model [20] could provide better estimation of sediment transport in sand-dominated zones, whereas the Wilcock and Crowe model [21] suits gravel-dominated mixed-size cases better. Török et al. [34] also proved that the combined and parallel application of these two models provides better results when simulating sediment transport in mixed-size bed material. In the referred study, a physical indicator was defined as a parameter to decide which formula is to be applied. It is, however, not evident what this parameter should be. In such cases, the prediction precision of the dominant fraction in the bed load transport plays an emphatic role in the accuracy of the sediment transport calculation possibilities.

\subsection{Existing Method for Bed Load Classification}

One applicable method, the Shields-Parker river sedimentation diagram, can be used as a comprehensive bed-material and sediment transport nature classification tool for a particular river reach, with uniform bed content [7]. The diagram indicates the Shields number $\left(\tau^{*}\right.$, or equivalently $\tau^{*} b f$, Equation (1)) based on the $d_{50}$ specific mean grain size versus the so-called explicit particle Reynolds number ( $R e_{p}$, Equation (2), where $d=d_{50}$ in the case of the Shields-Parker diagram). The diagram includes the well-known Shields curve (continuous black curve), which shows if the given particle is in motion (points above the curve), or remains still on the bed surface (points below the curve) [22].

$$
R e_{p}=\frac{\sqrt{g R d} d}{v}
$$

where $R=\left(\rho_{s}-\rho_{W}\right) / \rho_{W}, \rho_{W}$ is the water, $\rho_{s}$ is the sediment density, and $v$ is the kinematic viscosity of the fluid.

Parker stated [8] that alluvial rivers can usually be divided into two types based on the function of particle Reynolds number ( $R e_{p}$, Equation (2)): sand-bed and gravel-bed rivers. According to Parker, a distinction can be defined based on $R e_{p}$, which actually depends only on $d_{50}$ (therefore it can, in fact, be considered as the dimensionless substitution of the grain size). That is, considering that $d=2 \mathrm{~mm}$ is the threshold value between the sand and gravel fractions, the critical value for $R e_{p}$ also can be calculated according to Equation (1), where $d=2 \mathrm{~mm}$ results in $R e_{p}=360\left(R e_{p}>360 \rightarrow\right.$ gravel bed, $R e_{p}$ $<360 \rightarrow$ sand-bed), which critical value is depicted by a vertical narrow in Figure 3, within the $R e_{p}$ range of $100-1000$. 


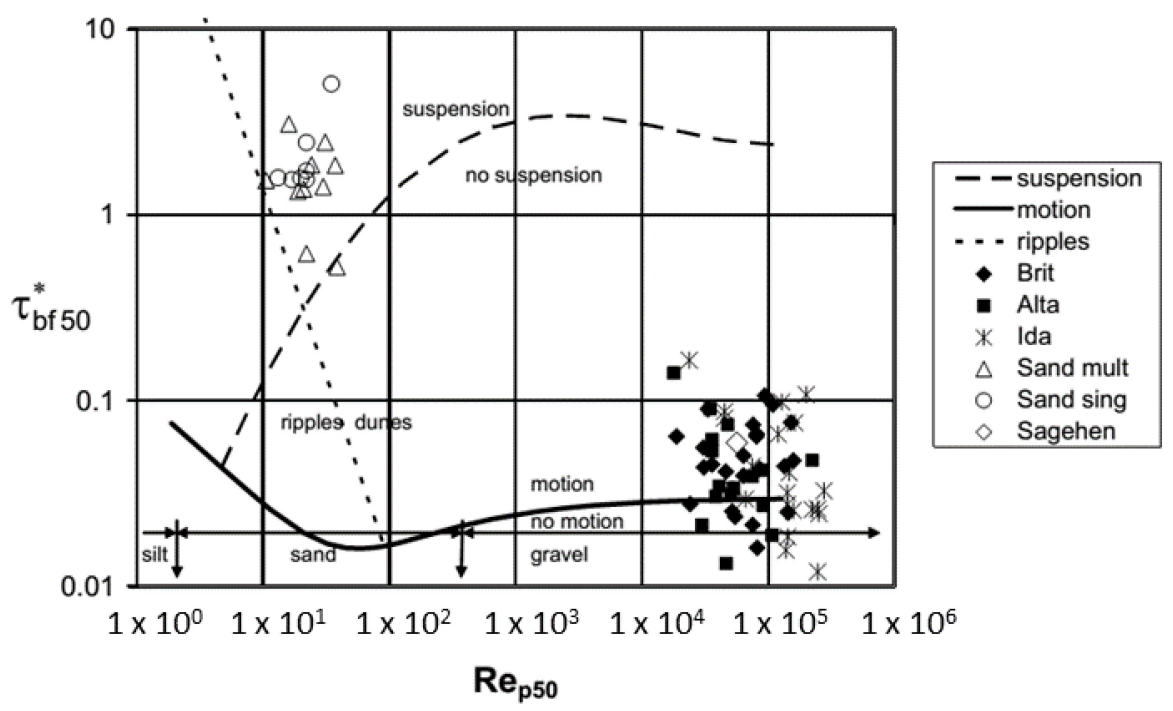

Figure 3. Shields-Parker diagram [7].

Consequently, the method basically yields a grain size-based classification method for near-uniform bed materials. This simplified approach is not capable of classifying characteristic local morphodynamic processes for complex situations in terms of river bed morphology and inhomogeneous bed material composition [7] (e.g., in the case of bed material in Figure 2).

The basic idea here is to keep the simplicity of the classification method shown by Parker, but at the same time to involve a new indicator, which accounts for the local hydrodynamic effects that better characterize the interaction between the water flow and the river bed, i.e., the bed shear stress. Thus, based on literature review, field and laboratory measurements, a conjecture is introduced in this paper. For a better understanding of the herein-proposed methodology, the most relevant findings of the related publications are summarized in the following.

\subsection{Introducing the Novel Method for Bed Load Classification}

Shields published a well-known study regarding sediment transport investigation in 1936 [22]. The research work investigated the critical state of the bed-forming particles, applying a mathematical model of forces acting on a solitary particle. Shields pointed out that the rate of the acting forces is not constant, but the relation of the effective force of the flow to the resistance of a grain can be expressed with a universal function of the shear Reynolds number ( $R e^{*}$, Equation (3)). The interpretation of the shear Reynolds number is expressed in Equation (3): the ratio of grain size to the thickness of the laminar boundary layer.

$$
\operatorname{Re}^{*}=\frac{u_{*} d}{v}=\frac{d}{v / u_{*}}=\frac{\text { Grain diameter }}{\text { Thickness of viscous layer }}
$$

where $u^{*}$ is the shear velocity $\left(u_{*}=\left(\frac{\tau}{\rho}\right)^{0.5}\right.$, where $\tau$ is the local bed shear stress). The following table demonstrates the difference between the shear Reynolds number and the explicit particle Reynolds number. The constant and the variable parameters in Equations (2) and (3) are depicted in Table 1. The last column indicates the ratio of $R e^{*}$ to $R e_{p}$. The main outcome of the table is that $R e^{*}$ implicates not only the grain size $(d)$, but also a term regarding the acting forces of the flow $\left(u^{*}\right)$. This remark confirms the $R e^{*}$-based investigation of Shields, instead of the $R e_{p}$-based method. 
Table 1. The constant and the variable parameters in the equations of the shear Reynolds number $\left(R e^{*}\right)$ and the explicit particle Reynolds number $\left(R e_{p}\right)$ (Equations (2) and (3)).

\begin{tabular}{cccc}
\hline & Constants $^{\mathbf{1}}$ & Variables & $\boldsymbol{R e}^{*} / \boldsymbol{R e}_{\boldsymbol{p}}$ \\
\cline { 3 - 3 }$e^{*}$ & $v$ & $d, u_{*}$ & $u_{*} / \sqrt{d}$ \\
$e_{p}$ & $v, g, R$ & $\mathrm{~d}$ & \\
\hline 1 The values of the constant terms are: $v=10^{-6} \frac{\mathrm{m}^{2}}{\mathrm{~s}}, g=9.81 \frac{\mathrm{m}}{\mathrm{s}^{2}}, R=1.65$.
\end{tabular}

The Shields curve, actually, shows the relation between the shear Reynolds number and the acting forces [22,45]. The investigation proves that the acting forces and the stability of a grain depend not on the grain sizes, but on the hydraulic regime formed directly above the grains $[7,46,47]$ (Considering the possible development of different kinds of turbulent flow pattern, e.g., in sand-bed rivers bed-form-induced turbulent flow, while in gravel-bed rivers, friction-induced turbulent pattern can occur [20,32,48-52]). It leads to two important consequences: (i) as the effective acting force depends not only on the grain size, but also on the acting forces of the flow, it is suggested that the sediment transport natures need to be classified based on the shear Reynolds number, too; (ii) due to this, the validation limits of the sediment transport-related mathematical models (that is, the sediment transport models) should be defined as the function of the shear Reynolds number.

The investigation of the applicability of the van Rijn bed load transport formula [20] also enhances the benefits of the shear Reynolds number-based investigation, against the grain-size-based (or characteristic grain-size-based). As one of the most widely tested and applied sediment transport formulas for river engineering applications, the van Rijn bed load transport equation [20] considers the application of the Shields curve. The transport model was developed and validated for sand transport measurements, and, therefore, the application limit was defined accordingly $(d<2 \mathrm{~mm})$ [7]. However, the validity range of the base mathematical model can be defined by the shear Reynolds number, and the grain size is not a suitable variable for this reason. Namely, the drag coefficient $\left(C_{D}\right)$, the lift coefficient $\left(\alpha_{L}\right)$, or the effect of the spinning motion depends on the shear Reynolds number [53-56], and the recommended values of these variables in the van Rijn model were calibrated and validated for lower shear Reynolds numbers $\left(R e^{*}<400\right)[20,57,58]$. Therefore, the determination of the applicability of the van Rijn model is reasonable as the function of the shear Reynolds number, which is the hydraulic smoother $\left(R e^{*}<400\right)$ regime.

At the same time, the lower $R e^{*}$ range implies lower bed shear velocity $\left(u^{*}\right)$ and smaller particles (d) (see Equation (3)), assuming the domination of the less-resistant finer fractions in the bed load and stable coarser grains. This is proved by the about 600 measurement data $[20,57,58]$. Also, Parker mentions [8] that, at rougher hydraulic regime $\left(R e^{*}>1000\right)$, the motion of the sand fractions is rather suspended like rolling. Consequently, finer fractions disappear from the bed load and the coarser gravels remain and become dominant. Accordingly, the van Rijn bed load model is not applicable in rougher hydraulic $\left(R e^{*}>1000\right)$ regime.

The laboratory experiments, where coarser $\left(d_{50}>5.3 \mathrm{~mm}\right)$ and nonuniform bed material conditions were investigated by Wilcock et al. [26], are also taken into consideration here. Figure 4 shows the rate of the gravel load to the sand load as the function of the shear Reynolds number. Within any mixtures, the higher the shear Reynolds number, the coarser the composition of the bed load. It is visible that the gravel load is equal to the sand load when the $R e^{*}$ is between 300 and 400 , around 350 (Figure 4). Above this, the gravel transport is dominant. In turn, below 350 the sand transport prevails, which underlines the earlier assumption, i.e., the fine sediment bed load transport takes place and dominates in the smoother hydraulic range. Consequently, despite that the $d_{50}$ characteristic grain size indicates only gravel transport, sand-dominated sediment transport was also found. 


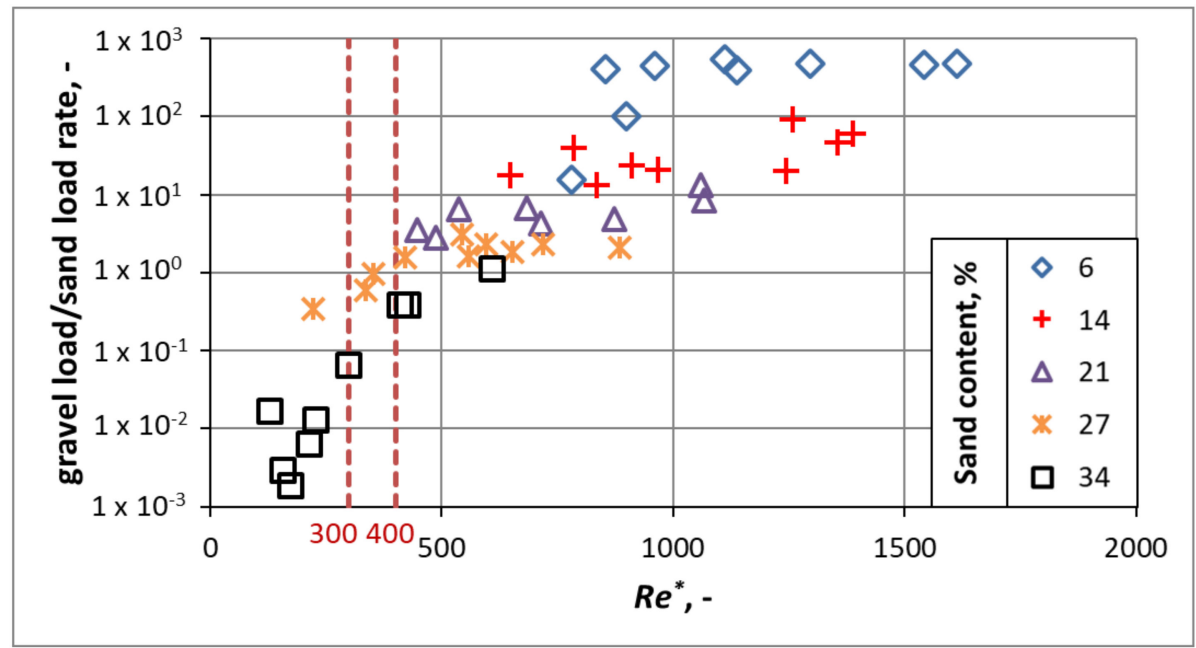

Figure 4. Calculated rates of the gravel load to the sand load as the function of the shear Reynolds number, based on the laboratory experiments of Wilcock et al. [26].

Based on the above-described summary, the following findings are emphasized

- Shields has already presented [22] that the shear Reynolds number $\left(R e^{*}\right)$ is a suitable variable (instead of the grain sizes) to define the relation of the acting forces and thus to classify the sediment transport in the near-surface zone. In other words, the effective force of the flow (together with the resistance of the grain) must be taken into account for the proper investigation of the stability and mobility of bed-forming particles.

- The applicability of both mathematical models of Shields [22] and van Rijn [20] can be described by the shear Reynolds number, but not by grain sizes. This also supports the fact that the shear Reynolds number-based classification of the sediment transport is expected to be more reliable than a grain-size-based method.

- The investigation of the measurements, for which the van Rijn bed load formula was validated and calibrated $[20,57,58]$, suggests that the sand bed load can occur at lower $R e^{*}$ range, $R e^{*}<400$. Complementing this by the statement of Parker [8], it is assumed that in rougher hydraulic regime $\left(R e^{*}>\sim 1000\right)$, the sand transport appears only in suspended form, while the bed load consists mainly of gravel.

- The $R e^{*}$-based assessment of the laboratory experiments of Wilcock et al. [26] shows that the $R e^{*}$ range 3-400 seems to be a critical zone, where the yield of the sand and gravel are roughly the same. A characteristic grain size cannot refer to such phenomena.

Accordingly, the following conjecture was stated: The $R e^{*}$ parameter is a more suitable parameter for the prediction and distinction of the sand- or gravel-dominated bed load transport, than either simply a characteristic grain size $\left(d_{90}\right.$ or $\left.d_{50}\right)$, or the $R e_{p}$. Moreover, $R e^{*}$ between $\sim 300$ and 400 seems to be a critical zone: above-gravel, below-sand domination can be expected in the bed load transport.

\subsection{Description of the Validation Measurements}

In order to investigate accuracy of the conjecture, an assessment considering characteristic local bed grain sizes, local bed shear stress values as well as calculated Reynolds numbers was performed using datasets from recent laboratory and field experiments of the authors. First, the results from the laboratory experiments of Török et al. [59] were used. In this experiment, morphological processes (scouring, bed armoring, and aggradation) were investigated around a single groin, using mixed-size bed material with an initial $d_{50}$ of $5.16 \mathrm{~mm}$. The local grain size distributions were determined by an automated image-based grain detection software tool BASEGRAIN [60]. Local bed shear stress values were estimated according to the TKE-Method [61] using the near-bed point-velocity measurements, 
carried out with a 3D Acoustic Doppler Velocimeter (ADV) [62]. The measurements were carried out at quasi-equilibrium bed geometry. Then, negligible bed changes were measured in the flume $(\Delta z< \pm 1 \mathrm{~mm} / \mathrm{h})$; however, weak bed load transport $\left(Q_{b}<0.3 \mathrm{~kg} / \mathrm{h}\right)$ of mainly the sand particles $\left(d_{50}=1.3 \mathrm{~mm}\right)$ could still be observed at the outlet of the flume, where the $d_{50}$ of the bed material ranged between 4 and $6 \mathrm{~mm}$ [59].

Second, field data from a section of a large river was also assessed. The field experiments were carried out in the Hungarian section of the Danube River at mean flow regime, where the main characteristic morphological parameters were already introduced in the Introduction point. Forty-seven bed material samples were taken by a drag-bucket sampler, for which the grain-size distributions of the samples were determined by sieving analysis [63]. Parallel to the local bed material samplings, time-averaged flow velocity profiles were measured by an acoustic Doppler current profiler (ADCP) (WorkHorse Rio Grande $1200 \mathrm{kHz}$ ) at the sampling locations. Based on these long-term, fixed-boat measurements, the local bed shear stress values could be estimated using the turbulent wall law [64]. No bed load sampling could be performed during the two measurement campaigns. However, the bed load rating curve at the closest monitoring station ( $6 \mathrm{~km}$ upstream) [17] represents that low, but not negligible, bed load transport took place during both measurements $\left(Q_{b}<0.1 \mathrm{~kg} / \mathrm{s}\right)$.

The data regarding the field and laboratory measurements can be found in Appendix A (Table A1).

\subsection{Measurement Data Processing for Validation Purpose of the Stated Conjecture}

Field and laboratory data from the above-introduced reach of the Danube River in Hungary and laboratory experiments were conducted to confirm the stated conjecture. In order to investigate the shear Reynolds number-based classification potential, the samples were sorted into three classes according to their origin place (Figures 5 and 6): the black squares refer to the sandy bed material samples, which were collected from the near-bank zones. Here, the bed material consists predominantly of silt and sand, gravel transport can be expected only during flood waves. The red stars originate from the side bars (e.g., bed material illustrated in Figure 2). As it was introduced in Chapter 2 and based on Figure 2, the dominant grain size in the bed load is variable (both sand and gravel can dominate) and it is strongly flow-dependent. Finally, the samples from the main channel are depicted by the blue diamonds. Based on the bed material analysis, only gravel transport can occur at this region of the channel, because sand can be vanishingly found. However, as the measurements indicate stable bed surface, pure gravel transport can be expected at mean flow conditions. The investigation examines whether the shear Reynolds number is a proper variable to separate the different classes of the points.

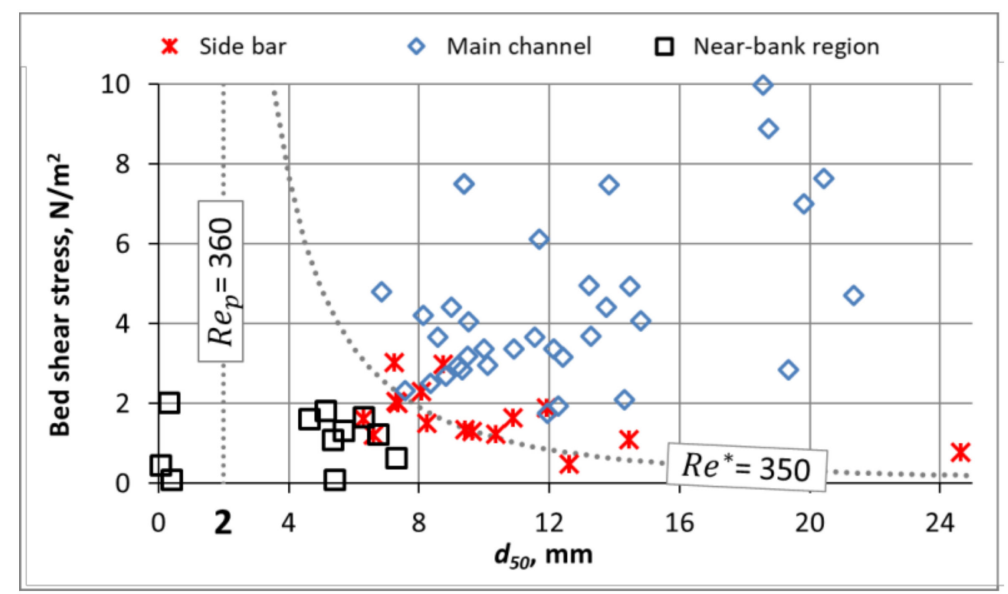

Figure 5. The bed shear stress as the function of the $d_{50}$ grain size, regarding field and laboratory measurements $[17,64]$. 




Figure 6. (A) Shields number as the function of the shear Reynolds number, based on laboratory and field data $[17,59,64]$. Shields curve is indicated with black line. (B) Shields number as the function of the explicit particle Reynolds number, based on laboratory and field data [17,59,64]. Shields curve is indicated with black line.

Furthermore, the comparison of the shear and particle Reynolds number-based investigations was also examined. First, the scattering of the three point classes as the function of $R e^{*}$ and $R e_{p}$ were compared. Based on this comparison, a more accurate separation method becomes outlined visually.

Finally, in order to perform a quantitative assessment on the performance of the $R e^{*}$ - and $R e_{p}$-based approaches, a statistical method was applied, which provides information on the representativity of the Reynolds number ranges for the characteristic bed load transport processes. Here, the log-normal distributions of the $R e^{*}$ and $R e_{p}$ values were calculated, separately for the three above-distinguished groups. The reason for using the log-normal distribution was the fact that asymmetric distributions were expected (based on the scattering of the points), where Re numbers cannot take negative values [65]. The probability density and the cumulative distribution functions are described in the Appendix A. Based on the cumulative distribution functions, the $R e^{*}$ - and $R e_{p}$-based separatenesses of the different point groups become qualitatively characterizable.

\section{Results}

First, the field measurement data were analyzed in Figure 5, separately. The scattering of the points reflects a clear tendency: the bed shear stress increases with higher grain sizes. Nevertheless, when indicating a separation line, which represents a $R e^{*}$ of 350 , the points from the three well-distinguishable regions indeed show different features. Points representing the shallower, sandy regions fall below the line. As most of these sampling locations can be characterized with mean grain sizes in the gravel range $\left(d_{50}>2 \mathrm{~mm}\right)$, the Shields-Parker diagram would consequently suggest clear gravel transport. However, considering the relatively low bed shear stress values $\left(<2 \mathrm{~N} / \mathrm{m}^{2}\right)$, the Shield curve predicts only sand motion (see the findings based on Figure 2, where $\tau^{*}=0.05 \rightarrow \tau \approx 2 \mathrm{~N} / \mathrm{m}^{2}$ ). Indeed, the $d_{50}$ of the bed material samples at the outlet of the flume $(4-6 \mathrm{~mm})$ would refer to gravel domination in the bed load, but the corresponding $d_{50}$ of the bed load samples show clear sand domination $(1.3 \mathrm{~mm})$ [59].

Second, the points distributed along the line belong to the bars. At this part of the points, the domination of sand or gravel cannot be well distinguished, but most probably a similar amount of them is transported. Accordingly, two phenomena can occur: (i) the bed shear stress values are low and the bed materials are quite uniform and coarse, resulting in resting particles (red stars, $\tau<\sim 1 \mathrm{~N} / \mathrm{m}^{2}$ ); (ii) higher flow transport capacity can cause almost the same order of magnitude in the sand and gravel discharge, if the bed material contains both fractions (red stars, where $\tau>\sim 2 \mathrm{~N} / \mathrm{m}^{2}$ and see also Figure 4).

Finally, the blue diamonds located above the line represent the stable $[17,59,64]$ main stream with coarse grains. Because of the armored bed surface, weak sediment transport occurs during mean flow 
discharge. Only higher flood waves can result in significant bed load transport [64], containing of local bed material, i.e., only gravel grains.

The constant particle Reynolds number of 360 values are indicated with a vertical dotted line. Unlike the separation line of $R e^{*}=350$, the particle Reynolds number does not distinguish the different point classes.

Assessing the relationship between local Shields number and the shear Reynolds number for both the laboratory and field experiments (Figure 6A), the statements in the previous paragraphs are corroborated regarding the $R e^{*}$-based classification of the landforms. Again, the $R e^{*} \approx 300-400$ range outlines as a suitable indicator for the identification whether the gravel or the sand particles dominate.

Contrarily, no clear distinction of the dominating morphodynamic processes can be made if the particle Reynolds number is considered (Figure 6B). Most of the points, representing all three different transport modes, range between $1000<R e_{p}<10,000$, clearly below the critical condition provided by Shields. Accordingly, a stable bed surface is expected both in the laboratory and in the field study. However, this is only the case for the armored sections of the study sites (blue diamonds) [17,59,64], whereas the bed load measurements of the laboratory experiments and the bed load rating curve at the study site in the Danube River demonstrate that weak bed load transport took place in both cases. Moreover, the bed load material investigation of the laboratory experiment suggested that the bed contained mainly sand fractions. Overall, despite the fact that the Shields curve would suggest stable bed, weak and sand-dominated bed load transport was monitored during the field and laboratory measurements.

Finally, the results of the log-normal-distribution-based probability examination are presented. As a summary of the calculations, the probability data was summarized for the six log-normal distributions, considering $R e^{*}=300, R e^{*}=400$, and $R e_{p}=360$ as critical values.

Table 2 shows that $5 \%$ of the near-bank points are in the $R e^{*}>300$ range, $60 \%$ of the gravel bar points take $R e^{*}$ between 300 and 400 , while only 3\% of the points from the main channel are expected below 400 . It can also be seen that, below the critical particle Reynolds number value $\left(d=2 \mathrm{~mm} ; R e_{p}=360\right)$, only the fine sediment transport nature can be expected. However, according to the log-normal distribution, $85 \%$ of the near-bank points are over 360 . Thus, the $R e_{p}=360$ indicates well that below this value mainly finer sediment transport is expected. In turn, the sediment transport nature cannot be determined obviously above this border.

Table 2. Probability values of the shear Reynolds number and the particle Reynolds number, calculated based on the fitted log-normal distribution for grouped data.

\begin{tabular}{cccccc}
\hline \multirow{2}{*}{ Landform Classes } & \multicolumn{3}{c}{$\boldsymbol{R} \boldsymbol{e}^{*}$} & \multicolumn{3}{c}{$\boldsymbol{R e}_{\boldsymbol{p}}$} \\
\cline { 2 - 6 } & $<\mathbf{3 0 0}$ & $<>$ & $>\mathbf{4 0 0}$ & $<360$ & $>\mathbf{3 6 0}$ \\
\hline Sand aggradation, near-bank points & $\mathbf{9 5 \%}$ & $5 \%$ & $0 \%$ & $15 \%$ & $85 \%$ \\
\hline Side bar & $5 \%$ & $\mathbf{6 0 \%}$ & $35 \%$ & $0 \%$ & $100 \%$ \\
\hline Main channel, bed armor & $0 \%$ & $3 \%$ & $\mathbf{9 7 \%}$ & $0 \%$ & $100 \%$ \\
\hline
\end{tabular}

The most important outcome of the probability analysis is that the $R e^{*}$ between 300 and 400 is indeed a critical range: below 300 the sand transport dominates, above 400 the gravel motion dominates.

The probability values indicated for the three main morphodynamic processes emphasize the suitability of $R e^{*}$ for the determination of the locally dominant grain size range in the bed load transport. On the other hand, the application of $R e_{p}$ suggests no clear classification for the same categorization, when spatially varied bed material is present, such as at the investigated river reach. 


\section{Discussion}

Previous studies report that the dominant sediment transport nature in rivers with uniform bed material can be reliably determined as the function of the so-called explicit particle Reynolds number $\left(R e_{p}\right)$, but yields less accurate estimations in cases when the bed material composition shows strong variability even along shorter reaches.

Based on the available and accessible data, namely 70 bed material samples and related local bed shear stress values gathered both from recent own laboratory and field experiments, it could be confirmed that, instead of the utilization of the explicit particle Reynolds number $\left(R e_{p}\right)$, or the application of characteristic grain sizes, e.g., $d_{50}$ or $d_{90}$, the shear Reynolds number $\left(R e^{*}\right)$ is a more adequate parameter to assess the locally dominant sediment transport nature. The probability calculations indicate that the sand-dominant bed load is estimable by $95 \%$ accuracy, while the gravel majority transport by $97 \%$. In contrast, the $R e_{p}$-based former method shows significantly greater inaccuracy. Although the gravel-dominated locations are estimated precisely, the method calculates the prediction of fine sediment majority by $85 \%$ inaccuracy.

Besides the authors' own experimental data, it could also be shown that the $R e^{*}$-based approach works reliably for the laboratory and field data based on which the widely used van Rijn [20,57,58] and the Wilcock and Crowe [26] bed load formulas were validated. The method is able to indicate the fine particle domination for all of the validation and calibration data of the van Rijn model correctly. Moreover, the transitional range between the sand and gravel majority becomes detectable in the case of sand-gravel mixture bed material measurements, with which the Wilcock and Crowe model was validated.

As another example, the authors assessed the datasets, consisting of 45 coupled bed shear stress $-d_{50}$ characteristic grain size value pairs from field measurements, published by Mueller et al. [66]. In that study, the median surface grain sizes of the gravel-bed streams and rivers were reported to vary between 0.027 and $0.21 \mathrm{~m}$, which indicates quite coarse bed material and armored bed surface. Accordingly, the calculated $R e^{*}$ are consequently high, all estimated $R e^{*}$ values exceed 400 .

Based on the data assessment introduced above, the following classification could be set up:

- $R e^{*}<\sim 300 \rightarrow$ sand transport dominates;

- $R e^{*}>\sim 400 \rightarrow$ gravel transport dominates;

- $\quad \sim 300<R e^{*}<\sim 400 \rightarrow$ gravel accumulating and side bar formation is expected.

Besides the promising validation results, the theory must be further proven by direct bed load field measurements. Also noted, that the local bed load content depends not only on the local bed material, but also on the arriving bed load material [67]. This obvious effect is not taken into account by the introduced method. Additionally, the benchmark measurements were carried out at weak bed load discharges. Thus, the validation needs to be extended to a wider range of the flow regime. However, the authors believe that the presented classification indicates meaningful progress in the investigation methods of the nonuniform bed load.

\section{Conclusions}

The herein-presented classification method of the locally dominant fraction in bed load transport can contribute to better implementation of different sediment transport investigation methods applied in large rivers. For instance, a well-known issue related to field sediment transport monitoring is the high uncertainty of direct bed load sampling methods. Having information on the local bed material and on the flow field, the offered $R e^{*}$-based approach can suggest where and what sort of sampling techniques would be the most suitable to collect reliable sediment information.

The results can also contribute to the development of improved computational modeling tools. Indeed, instead of applying one specific empirical sediment transport formula in a simulation to calculate local bed load transport, the $R e^{*}$-based approach can be utilized to distinguish between 
several formulas, each of them having a certain application range. Thus, the combined use of several formulas becomes possible.

Author Contributions: G.T.T. conceived the study, collected the data, conducted the data analysis, preformed the statistical analysis and drafted the manuscript. G.T.T. and S.B. discussed the results. S.B. worked on subsequent drafts of the manuscript. S.B. and J.J. participated in the design and coordination of the study.

Funding: This research was supported by the ÚNKP-17-3 and 17-4 New National Excellence Program of the Ministry of Human Capacities, which is highly appreciated, and was partly supported by MTA TKI of the Hungarian Academy of Sciences. Support of grant BME FIKP-VÍZ by EMMI is also kindly acknowledged. The authors acknowledge the funding of the OTKA FK 128429 grant.

Conflicts of Interest: The authors declare no conflict of interest.

\section{Appendix A}

The probability density function for the log-normal distribution is expressed as:

$$
P(x)=\frac{1}{x \sigma \sqrt{2 \pi}} e^{-\frac{1}{2}\left(\frac{\ln x-u}{\sigma}\right)^{2}},
$$

where the parameters are $-\infty<\mu<\infty$ (scale parameter) and $\sigma>0$ (shape parameter), can be obtained by the fitting of the function to the known points. The integration of the log-normal distribution curves results in the cumulative distribution function, which is:

$$
F(x)=\Phi\left(\frac{\ln x-u}{\sigma}\right),
$$

where $\Phi$ is the Laplace integral $[68,69]$. 
Table A1. Measured morphodynamic data of field $[17,64]$ (at the introduced reach of the Danube River in Hungary) and laboratory [59] measurements and of the referenced laboratory experiments $[17,59,64]$.

\begin{tabular}{|c|c|c|c|c|c|c|c|c|c|c|c|c|c|c|c|}
\hline & \multicolumn{5}{|c|}{ Main Channel, Bed Armor } & \multicolumn{5}{|c|}{ Sand Aggradation, Near-Bank Points } & \multicolumn{5}{|c|}{ Side Bar } \\
\hline & $\boldsymbol{u} *$ & $\tau^{*}$ & $R e^{*}$ & $R e_{p}$ & $d_{50}$ & $\boldsymbol{u} *$ & $\tau^{*}$ & $R e^{*}$ & $\boldsymbol{R} e_{p}$ & $d_{50}$ & $u *$ & $\tau^{*}$ & $R e^{*}$ & $R e_{p}$ & $d_{50}$ \\
\hline \multirow{32}{*}{ 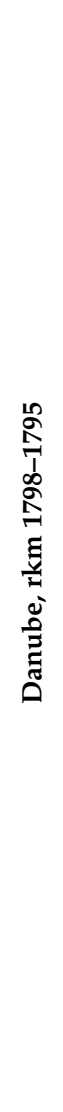 } & 0.054 & 0.020 & 498 & 3546 & 9.2 & 0.025 & 0.005 & 185 & 2512 & 7.3 & 0.022 & 0.002 & 276 & 5705 & 12.6 \\
\hline & 0.053 & 0.009 & 1031 & 10,835 & 19.4 & 0.010 & 0.001 & 55 & 1604 & 5.4 & 0.035 & 0.007 & 364 & 4242 & 10.4 \\
\hline & 0.046 & 0.009 & 657 & 6886 & 14.3 & 0.022 & 0.062 & 1 & 1 & 0.0 & 0.028 & 0.002 & 689 & 15,567 & 24.6 \\
\hline & 0.042 & 0.009 & 500 & 5252 & 11.9 & 0.129 & 0.062 & 16 & 6 & 0.1 & 0.033 & 0.006 & 478 & 6995 & 14.5 \\
\hline & 0.058 & 0.019 & 633 & 4583 & 10.9 & 0.128 & 0.062 & 136 & 140 & 1.1 & 0.036 & 0.008 & 347 & 3802 & 9.6 \\
\hline & 0.061 & 0.020 & 701 & 5005 & 11.6 & 0.045 & 0.399 & 14 & 23 & 0.3 & 0.041 & 0.009 & 443 & 4577 & 10.9 \\
\hline & 0.066 & 0.030 & 598 & 3429 & 9.0 & 0.010 & 0.016 & 4 & 33 & 0.4 & 0.037 & 0.009 & 347 & 3676 & 9.4 \\
\hline & 0.044 & 0.010 & 540 & 5481 & 12.3 & & & & & & 0.044 & 0.010 & 519 & 5231 & 11.9 \\
\hline & 0.069 & 0.014 & 1465 & 12,559 & 21.4 & & & & & & & & & & \\
\hline & 0.058 & 0.003 & 3745 & 65,995 & 64.6 & & & & & & & & & & \\
\hline & 0.100 & 0.033 & 1855 & 10,182 & 18.6 & & & & & & & & & & \\
\hline & 0.064 & 0.026 & 605 & 3737 & 9.5 & & & & & & & & & & \\
\hline & 0.064 & 0.017 & 946 & 7251 & 14.8 & & & & & & & & & & \\
\hline & 0.069 & 0.043 & 475 & 2283 & 6.9 & & & & & & & & & & \\
\hline & 0.094 & 0.029 & 1766 & 10,314 & 18.7 & & & & & & & & & & \\
\hline & 0.084 & 0.022 & 1659 & 11,230 & 19.8 & & & & & & & & & & \\
\hline & 0.087 & 0.049 & 813 & 3658 & 9.4 & & & & & & & & & & \\
\hline & 0.056 & 0.021 & 535 & 3715 & 9.5 & & & & & & & & & & \\
\hline & 0.048 & 0.019 & 365 & 2657 & 7.6 & & & & & & & & & & \\
\hline & 0.087 & 0.049 & 813 & 3658 & 9.4 & & & & & & & & & & \\
\hline & 0.053 & 0.019 & 499 & 3631 & 9.3 & & & & & & & & & & \\
\hline & 0.058 & 0.021 & 581 & 4026 & 10.0 & & & & & & & & & & \\
\hline & 0.077 & 0.007 & 3955 & 46,694 & 51.3 & & & & & & & & & & \\
\hline & 0.049 & 0.004 & 1956 & 31,713 & 39.6 & & & & & & & & & & \\
\hline & 0.079 & 0.012 & 2543 & 23,129 & 32.1 & & & & & & & & & & \\
\hline & 0.061 & 0.005 & 3042 & 44,346 & 49.5 & & & & & & & & & & \\
\hline & 0.082 & 0.006 & 5374 & 67,130 & 65.3 & & & & & & & & & & \\
\hline & 0.060 & 0.005 & 2896 & 42,850 & 48.4 & & & & & & & & & & \\
\hline & 0.073 & 0.006 & 3714 & 46,211 & 50.9 & & & & & & & & & & \\
\hline & 0.048 & 0.005 & 1449 & 21,195 & 30.3 & & & & & & & & & & \\
\hline & 0.066 & 0.020 & 913 & 6486 & 13.7 & & & & & & & & & & \\
\hline & 0.079 & 0.013 & 2345 & 20,525 & 29.6 & & & & & & & & & & \\
\hline \multirow{13}{*}{ 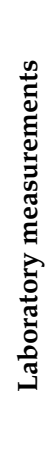 } & 0.065 & 0.032 & 528 & 2951 & 8.1 & 0.040 & 0.022 & 186 & 1262 & 4.6 & 0.035 & 0.011 & 228 & 2155 & 6.6 \\
\hline & 0.078 & 0.032 & 915 & 5087 & 11.7 & 0.033 & 0.013 & 177 & 1570 & 5.3 & 0.055 & 0.026 & 398 & 2481 & 7.2 \\
\hline & 0.070 & 0.023 & 930 & 6118 & 13.2 & 0.036 & 0.014 & 207 & 1727 & 5.7 & 0.055 & 0.021 & 478 & 3287 & 8.7 \\
\hline & 0.060 & 0.026 & 518 & 3194 & 8.6 & 0.043 & 0.022 & 219 & 1474 & 5.1 & 0.045 & 0.017 & 329 & 2537 & 7.4 \\
\hline & 0.086 & 0.033 & 1197 & 6548 & 13.8 & 0.041 & 0.016 & 257 & 2015 & 6.3 & 0.039 & 0.011 & 320 & 3016 & 8.3 \\
\hline & 0.058 & 0.017 & 704 & 5374 & 12.1 & 0.035 & 0.011 & 237 & 2220 & 6.7 & 0.045 & 0.017 & 330 & 2506 & 7.3 \\
\hline & 0.061 & 0.017 & 805 & 6151 & 13.3 & & & & & & 0.048 & 0.018 & 387 & 2914 & 8.1 \\
\hline & 0.070 & 0.021 & 1018 & 7012 & 14.5 & & & & & & 0.040 & 0.016 & 253 & 2005 & 6.3 \\
\hline & 0.056 & 0.016 & 697 & 5558 & 12.4 & & & & & & & & & & \\
\hline & 0.054 & 0.018 & 549 & 4084 & 10.1 & & & & & & & & & & \\
\hline & 0.087 & 0.023 & 1785 & 11,739 & 20.4 & & & & & & & & & & \\
\hline & 0.050 & 0.019 & 417 & 3066 & 8.3 & & & & & & & & & & \\
\hline & 0.052 & 0.019 & 459 & 3339 & 8.8 & & & & & & & & & & \\
\hline
\end{tabular}

\section{References}

1. Dey, S. Fluvial Processes: Meandering and Braiding. In Fluvial Hydrodynamics: Hydrodynamic and Sediment Transport Phenomena; Springer: Berlin/Heidelberg, Germany, 2014; pp. 529-562.

2. Leopold, B.L.; Wolman, M.G. River Channel Patterns: Braided, Meandering and Straight; Geological Survey Professional Paper; U.S. Government Printing Office: Washington, DC, USA, 1957; Volume 282.

3. Lane, E.W. A Study of the Shape of Channels Formed by Natural Streams Flowing in Erodible Material; U.S. Army Corps of Engineers Report; The Division: Omaha, NE, USA, 1957; Volume 141.

4. Leopold, L.B.; Wolman, M.G. River meanders. Geol. Soc. Am. Bull. 1960, 71, 769-794. [CrossRef]

5. Schumm, S.A. Evolution and response of the fluvial system, sedimentologic implications. SEPM Spec. Publ. $1981,31,19-29$. 
6. Jaeggi, M.N.R. Effect of Engineering Solutions on Sediment Transport. In Dynamics of Gravel-Bed Rivers; Billi, P., Hey, R.D., Thorne, C.R., Tacconi, P., Eds.; John Wiley \& Sons Ltd.: Hoboken, NJ, USA, 1992.

7. García, M.H. Sediment Transport and Morphodynamics. In Sedimentation Engineering: Processes, Measurements, Modeling, and Practice, Manuals and Reports on Engineering Practice; ASCE: Reston, VA, USA, 2008; pp. 21-163.

8. Parker, G. Transport of Gravel and Sediment Mixtures. In Sedimentation Engineering; Garcia, M., Ed.; American Society of Civil Engineers: Reston, VA, USA, 2008; ISBN 978-0-7844-0814-8.

9. Schumm, S.A.; Dumont, J.F.; Holbrook, J.M. Active Tectonics and Alluvial Rivers; Cambridge University Press: Cambridge, UK; New York, NY, USA; Melbourne, Australia, 2000; ISBN 0-521-66110-2.

10. Edward, J. Hickin. Chapter 4. In Fluid Mechanics; Online course note; Simon Fraser University and R.S. Graphics and Printing: Burnaby, BC, Canada, 2009.

11. Piton, G.; Recking, A. The concept of travelling bedload and its consequences for bedload computation in mountain streams. Earth Surf. Process. Landf. 2017, 42, 1505-1519. [CrossRef]

12. Farkas-Iványi, K.; Guti, G. The Effect of Hydromorphological Changes on Habitat Composition of the Szigetköz Floodplain. ACTA Zool. Bulg. 2014, 7, 117-121.

13. Hankó, Z.; Starosolszky, Ö.; Bakonyi, P. Megvalósíthatósági tanulmány a Duna környezetének és hajózhatóságának fejlesztésére (Danube Environmental and navigation Project, Feasibility Study). Vizügyi Közlemények 1996, 78, 291-315.

14. Rákóczi, L. A Duna-meder sorsa Szap és Szob között (Destiny of the Danube channel between Szap and Szob). Vizügyi Közlemények 2000, 82, 262-280.

15. Goda, L. A Duna gázlói Pozsony-Mohács között (Shallows of the River Danube between Pozsony, Bratislava and Mohács. Vizügyi Közlemények 1995, 77, 71-102.

16. Baranya, S.; Józsa, J.; Török, G.T.; Ficsor, J.; Mohácsiné Simon, G.; Habersack, H.; Haimann, M.; Riegler, A.; Liedermann, M.; Hengl, M. A Duna hordalékvizsgálatai a SEDDON osztrák-magyar együttmúködési projekt keretében (Introduction of the joint Austro-Hungarian sediment research under the SEDDON ERFE-project). Hidrológiai Közlöny 2015, 95, 41-46.

17. Török, G.T.; Baranya, S. Morphological investigation of a critical reach of the upper Hungarian Danube. Period. Polytech. Civ. Eng. 2017, 61. [CrossRef]

18. Észak-Dunántúli Vízügyi Igazgatóság. Nagyvízi mwe haederkezelési terv (High Water River Management Plan) 01.nmt.02. (egyeztetési terv)—Duna 1809,76-1786,00fkm; 2014; Professional report; Észak-Dunántúli Vízügyi Igazgatóság: Győr, Hungary, 2014.

19. Liedermann, M.; Gmeiner, P.; Pessenlehner, S.; Haimann, M.; Hohenblum, P.; Habersack, H. A Methodology for Measuring Microplastic Transport in Large or Medium Rivers. Water 2018, 10, 414. [CrossRef]

20. Van Rijn, L.C. Sediment Transport, Part I: Bed Load Transport. J. Hydraul. Eng. 1984, 110, 1431-1456. [CrossRef]

21. Wilcock, P.R.; Crowe, J.C. Surface-based transport model for mixed-size sediment. J. Hydraul. Eng. 2003, 129, 120-128. [CrossRef]

22. Shields, A. Application of Similarity Principles and Turbulence Research to Bed-Load Movement. Mitt. Preuss. Versuchsanst. Wasserbau Schiffbau 1936, 26, 47.

23. Bergillos, R.J.; Rodrígez-Delgado, C.; Millares, A.; Ortega-Sánchez, M.; Losada, M.A. Impact of river regulation on a Mediterranean delta: Assessment of managed versus unmanaged scenatios. Water Resour. Res. 2016, 52, 5132-5148. [CrossRef]

24. Bergillos, R.J.; Ortega-Sánchez, M.; Masselink, G.; Losada, M.A. Morpho-sedimentary dynamics of a micro-tidal mixed sand and gravel beach, Playa Granada, southern Spain. Mar. Geol. 2016, 379, $28-38$. [CrossRef]

25. Fischer-Antze, T.; Rüther, N.; Olsen, N.; Gutknecht, D. Three-dimensional (3D) modeling of non-uniform sediment transport in a channel bend with unsteady flow. J. Hydraul. Res. 2009, 47, 670-675. [CrossRef]

26. Wilcock, P.R.; Kenworthy, S.T.; Crowe, J.C. Experimental Study of the Transport of Mixed Sand and Gravel. Water Resour. Res. 2001, 37, 3349-3358. [CrossRef]

27. Wilcock, P.R. A two-fraction model for the transport of sand/gravel mixtures. Water Resour. Res. 2002, 38, 1-12. [CrossRef]

28. Sziło, J.; Bialik, R.J. Grain Size Distribution of Bedload Transport in a Glaciated Catchment (Baranowski Glacier, King George Island, Western Antarctica). Water 2018, 10, 360. [CrossRef] 
29. Bialik, R.J. Numerical study of saltation of non-uniform grains. J. Hydraul. Res. 2011, 49, 697-701. [CrossRef]

30. Einstein, H.A. The Bed-Load Function for Sediment Transportation in Open Channel Flows; Department of Agriculture, Soil Conservation Service: Washington, DC, USA, 1950.

31. Ashida, K.; Michiue, M. Study on hydraulic resistance and bedload transport rate in alluvial streams. Trans. Jpn. Soc. Civ. Eng. 1972, 206, 59-69. [CrossRef]

32. Meyer-Peter, E.; Müller, R. Formulas for Bed-Load Transport. In Proceeding of the IAHSR 2nd Meeting, Stockholm, Sweden, 7-9 June 1948.

33. Wiberg, P.L.; Smith, J.D. Model for calculating bed load transport of sediment. J. Hydraul. Eng. 1989, 115, 101-123. [CrossRef]

34. Török, G.T.; Baranya, S.; Rüther, N. 3D CFD Modeling of Local Scouring, Bed Armoring and Sediment Deposition. Water 2017, 9, 56. [CrossRef]

35. Gaeuman, D.; Andrews, E.D.; Krause, A.; Smith, W. Predicting fractional bed load transport rates: Application of the Wilcock-Crowe equations to a regulated gravel bed river. Water Resour. Res. 2009, 45, 1-15. [CrossRef]

36. Janssen, S.R. Testing Sediment Transport Models under Partial Transport Conditions. Master's Thesis, University of Twente, Enschede, The Netherlands, 2010.

37. Török, G.T.; Baranya, S.; Rüther, N. Three-dimensional numerical modeling of non-uniform sediment transport and bed armoring process. In Proceedings of the 18th Congress of the Asia \& Pacific Division of the International Association for Hydro-Environment Engineering and Research, Jeju, Korea, 19-23 August 2012.

38. Rüther, N.; Olsen, N.R.B. Modelling free-forming meander evolution in a laboratory channel using three-dimensional computational fluid dynamics. Geomorphology 2007, 89, 308-319. [CrossRef]

39. Rüther, N.; Olsen, N.R.B. 3D modeling of transient bed deformation in a sine-generated laboratory channel with two different width to depth ratios. In Proceedings of the International Conference on Fluvial Hydraulics, Lisbon, Portugal, 6-8 September 2006; Taylor \& Francis: New York, NY, USA, 2006.

40. Rüther, N.; Olsen, N.R.B. Three-dimensional modeling of sediment transport in a narrow $90^{\circ}$ channel bend. J. Hydraul. Eng. 2005, 131, 917-920. [CrossRef]

41. Olsen, N.R.B.; Melaaen, M.C. Three-dimensional calculation of scour around cylinders. J. Hydraul. Eng. 1993, 119, 1048-1054. [CrossRef]

42. Bihs, H.; Olsen, N.R.B. Numerical Modeling of Abutment Scour with the Focus on the Incipient Motion on Sloping Beds. J. Hydraul. Eng. 2011, 137, 1287-1292. [CrossRef]

43. Deltares. 3D/2D modelling suite for integral water solutions. Delft3D-FLOW, User Manual; Deltares: Delft, The Netherlands, 2014; Volume 710.

44. Skinner, C.J.; Coulthard, T.J.; Schwanghart, W.; Van De Wiel, M.J.; Hancock, G. Global sensitivity analysis of parameter uncertainty in landscape evolution models. Geosci. Model Dev. 2018, 11, 4873-4888. [CrossRef]

45. Unal, N.E. Shear Stress-Based Analysis of Sediment Incipient Deposition in Rigid Boundary Open Channels. Water 2018, 10, 1399. [CrossRef]

46. Habersack, H.; Kreisler, A. Sediment Transport Processes. In Dating Torrential Processes on Fans and Cones; Beniston, M., Ed.; Springer: Dordrecht, The Netherlands; Heidelberg, Germany; New York, NY, USA; London, UK, 2013; ISBN 9789400743359.

47. Zanke, U.C.E. Hydromechanik der Gerinne und Küstengewässer; Blackwell; Vieweg+Teubner Verlag: Berlin, Germany, 2002; ISBN 978-3-322-80212-5.

48. Parker, G.; Klingeman, P.C. On why gravel rivers are paved. Water Resour. Res. 1982, 18, 1409-1423. [CrossRef]

49. Cushman-Roisin, B. Rivers and Streams, Chapter 15. In Environenmental Fluid Mechanics; John Wiley \& Sons, Inc.: Hanover, NH, USA, 2019.

50. Parker, G. Surface-based bedload transport relation for gravel rivers. J. Hydraul. Res. 1990, 28, 417-436. [CrossRef]

51. Dey, B.S.; Papanicolaou, A. Sediment Threshold under Stream Flow: A State-of-the-Art Review. KSCE J. Civ. Eng. 2008, 12, 45-60. [CrossRef]

52. Dwivedi, A.; Melville, B.W.; Shamseldin, A.Y.; Guha, T.K. Analysis of hydrodynamic lift on a bed sediment particle. J. Geophys. Res. 2011, 116. [CrossRef]

53. Morsi, S.A.; Alexander, A.J. An investigation of particle trajectories in two phase flow systems. J. Fluid Mech. 1972, 55, 193-208. [CrossRef] 
54. Rubinow, S.I.; Keller, J.B. The transverse force on a spinning sphere moving in a viscous fluid. J. Fluid Mech. 1961, 11, 447-459. [CrossRef]

55. Saffman, P.G. The lift on a small sphere in a slow shear flow. J. Fluid Mech. 1965, 22, 385-400. [CrossRef]

56. Dey, S. Sediment threshold. Appl. Math. Model. 1999, 23, 399-417. [CrossRef]

57. Fernandez Luque, R. Erosion and Transport of Bed-load Sediment. BSc Thesis, Delft Technical University, Delft, The Netherlands, 1974.

58. Fernandez Luque, R.; van Beek, R. Erosion and Transport of Bed-load Sediment. J. Hydraul. Res. 1976, 14, 127-144. [CrossRef]

59. Török, G.T.; Baranya, S.; Rüther, N.; Spiller, S. Laboratory analysis of armor layer development in a local scour around a groin. In Proceedings of the International Conference on Fluvial Hydraulics, RIVER FLOW 2014, Lausanne, Switzerland, 3-5 September 2014; Taylor and Francis Group: Lausanne, Switzerland, 2014; pp. 1455-1462.

60. Detert, M.; Weitbrecht, V. User guide to gravelometric image analysis by BASEGRAIN. In Advances in River Sediment Research; Fukuoka, S., Nakagawa, H., Sumi, T., Zhang, H., Eds.; CRC Press: Boca Raton, FL, USA, 2013; ISBN 9781138000629.

61. Kim, S.C.; Friedrichs, C.T.; Maa, J.P.Y.; Wright, L.D. Estimating bottom stress in tidal boundary layer from Acoustic Doppler velocimeter data. J. Hydraul. Eng. 2000, 126, 399-406. [CrossRef]

62. Cea, L.; Puertas, J.; Pena, L. Velocity measurements on highly turbulent free surface flow using ADV. Exp. Fluids 2007, 42, 333-348. [CrossRef]

63. Przyborowski, Ł.; Loboda, A.M.; Bialik, R.J. Experimental investigations of interactions between sand wave movements, flow structure, and individual aquatic plants in natural rivers: A case study of Potamogeton Pectinatus, L. Water 2018, 10, 1166. [CrossRef]

64. Török, G.T. Methodological Improvement of Morphodynamic Investigation Tools for Rivers with Non-Uniform Bed Material By. Ph.D. Thesis, Budapest University of Technology and Economics, Budapest, Hungary, 2018.

65. Koris, K. Hidrológia II. (Hydrology II); 1. kiadás.; Class note (Egyetemi jegyzet): Budapest, Hungary, 2014; ISBN 978-963-12-0752-1.

66. Mueller, E.R.; Pitlick, J.; Nelson, J.M. Variation in the reference Shields stress for bed load transport in gravel-bed streams and rivers. Water Resour. Res. 2005, 41. [CrossRef]

67. Vowinckel, B.; Jain, R.; Kempe, T.; Fröhlich, J. Entrainment of single particles in a turbulent open-channel flow: A numerical study. J. Hydraul. Res. 2016, 54, 158-171. [CrossRef]

68. EasyFit Professional, Version 5; MathWave Technologies: Washington, DC, USA, 2015.

69. Aristizabal, R.J. Estimating the Parameters of the Three-Parameter Lognormal Distribution. FIU Electronic Theses and Dissertation, Florida International University, St. Miami, FL, USA, 2012. 